\title{
PRIVATE EXPLORATION
}

\section{A crude result.}

\section{BY T. C. MCCARTHY}

$I$ thad to be crude oil, Terrell thought. He adjusted the sample again and then his face mask, forcing himself to stay calm. The shimmer was there, the rock like one of the shales he had studied in Sweden, except that Terrell knew it came from someplace much farther away, and the shimmer was what everyone wanted to find, but which nobody dreamed they would. Terrell switched to ultraviolet light and the rock glowed in confirmation as if smiling back, daring him to throw all the tests at it he could, that it wasn't scared and he should just go ahead. "I double dare you," it would have said - if rocks could talk.

\section{Oil! On Mars!}

Margaret sat in the next station, her hair covered and a mask hiding everything except her nose and glasses. Terrell watched for a minute, not sure what to say.

"Margaret, where did my rock came from again? T-one-seven-one-alpha?"

"Mars," she said dryly.

"Ha, ha. Seriously. Which mission?" There had been three separate core-return missions that just got back, and Terrell didn't really have to get an answer from Margaret, he could have looked for himself. But it was the first thing that popped into his head. Margaret asked for the number again and then checked.

"Mission Two, Midland Petroleum, and your sample's from the core bottom, the deepest section. Everything else from that one was evaporite. Evaporite, evaporite, evaporite, just like Mission One cores, just like Mission Three's, and just like every single mission before if you don't count all the basalt. Why? Find any oil?"

Terrell almost said yes, but it was the same sarcasm she always used and he laughed it off, instead saying something like, yeah, a whole barrel of it. "Ever think about what would happen?"

"What would happen where? When?"

Terrell turned off his microscope. "If we found oil. On Mars."

"Yeah, now that you mention it." She became animated, and he saw an angry glare in her eyes, one that mirrored her voice. "I think about it all the time. The day Mars was finally colonized, but not by explorers. By Midland and a hundred other corporations who killed each other to buy up all the

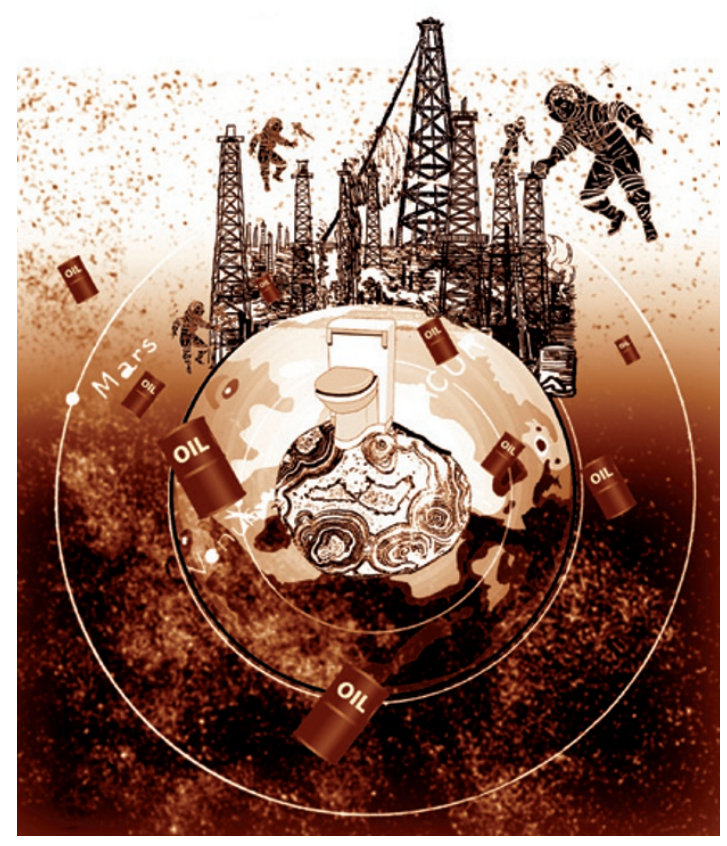

things through, hadn't considered the ramifications of what he was doing, 녹 because what if Margaret was right? Terrell's shoulder patch said Corchoran. It was short for Corchoran Diversified, a services company that contracted for just about everything, and once the professorships hadn't panned out, it was the only job Terrell had found, the only one that offered insurance, the only geology job anywhere - subcontracting samplereturn analyses for the Mars missions, all of them privately funded. But these would be the last three missions and once the analyses were done, he'd hit the street again for interview after interview until he finally wound up delivering pizzas. The truth of it hit him then: Corchoran didn't give a damn either.

There was no telling if the cameras were watching. They were always on, always pointed at them from inside their sterile booths, and as soon as he decided what he'd do, Terrell felt sweat on his forehead.

land rights, and then sent company geologists to drill, company executives hopping a ride just so they could say that they'd been to Mars. And the drillers. Don't get me started on drillers, I don't want to know what they'd do without their brothels. Think about it. When would anyone let colonists onto Mars in that scenario?"

Terrell thought but couldn't answer, and then shook his head. "When?"

"Just as soon as Mars was destroyed, covered with muck piles, empty mud pits, and spilled oil. After nobody wants to see Mars."

"It wouldn't be that bad," said Terrell. But already he wished he hadn't said anything.

"Really? I'm from west Texas. Ever been to west Texas?"

"No. Never been west of Houston."

Margaret pointed at him as if she had triumphed. "Exactly."

"So why are you working here?" he asked. "Why bother?"

"Same reason as you." Margaret returned to her microscope, adjusting the light and magnification before she looked back a moment later. "Where else can a petroleum geologist find work these days?"

"Yeah," said Terrell. "Where else."

The smile had abandoned him. In fact, $\rightarrow$ NATURE.COM

Follow Futures on

Facebook at:

go.nature.com/mtoodm his excitement had also drained completely, leaving only a sickening sensation that once again he hadn't thought
It was a 50-50 shot; the guard would either be watching him or Margaret. He opened the sample container and pretended to put the rock inside, palming it instead, and once outside the booth, with Margaret calling out to ask where he was going, he stepped into the prep room and began taking off his gloves, booties and apron. Terrell slipped the rock into a shoe, deep, where he felt it under his foot. He did his best not to limp. Less than a minute later he had got through the pocket search, the guard paying only half attention to his explanation that he needed to use the can, before Terrell slipped into the bathroom. He shut the stall door and pulled his shoes off, and stared at the rock one last time. It only took a second to drop it in the toilet. Terrell flushed twice. He didn't bother to get his things then, but instead left through the front door in socks. It was all Terrell could do to stop thinking about what he had just thrown away, especially once he realized they'd probably arrest him. But those thoughts didn't last long. Four words took their place, running through his mind like a steady drum beat, over and over until he grinned.

Crude oil. On Mars!

T. C. McCarthy's fiction has appeared in Per Contra and will soon appear in Story Quarterly. His debut novel, Germline, is forthcoming in 2011 from Orbit Books. Visit T. C. at www.tcmccarthy.com. 